\title{
A FUZZY ANALYTIC NETWORK PROCESS APPROACH TO DETERMINING PROSPECTIVE COMPETITIVE STRATEGY IN CHINA: A CASE STUDY FOR MULTINATIONAL BIOTECH PHARMACEUTICAL ENTERPRISES
}

\author{
Yun-Huei Lee \\ Department of Business Administration, Tamkang University, Taipei, Taiwan, R.O.C. \\ E-mail:yh@mail.tku.edu.tw
}

Received 19 April 2011; accepted 01 June 2011

\begin{abstract}
This study explores efforts to identify the most appropriate competitive strategy relative to multinational biotech pharmaceutical enterprises' strategy selection. The research uses the analytic network process (ANP) technique combining both qualitative and quantitative information to construct a hierarchical model involving interactions among various criteria for competitive strategy selection, and also introduces fuzzy logic to eliminate vagueness, subjectivity, and imprecision stemming from human judgment. The most important finding shows that the most suitable competitive strategy for multinational enterprises (MNEs) is innovative-focus strategy. Also, the weighted calculations present the three most important criteria affecting the competitive strategy of foreign direct investment (FDI): collaboration with local partners, governmental rules and regulations and high-quality research personnel with R \& D capability.
\end{abstract}

Keywords: competitive-strategy selection, fuzzy analytic network process (FANP), foreign direct investment (FDI), multinational biotech pharmaceutical enterprises.

Reference to this paper should be made as follows: Lee, Y.-H. 2012. A fuzzy analytic network process approach to determining prospective competitive strategy in China: a case study for multinational biotech pharmaceutical enterprises, Journal of Business Economics and Management 13(1): 5-28.

JEL Classification: C63, F23, M00.

\section{Introduction}

Since implementing an open-door policy in 1978, China has witnessed dramatic growth in the large amounts of inflow of foreign direct investment (FDI) into China. China has replaced the United States, becoming the largest recipient of FDI in 2003. China has successfully attracted FDI from multinational enterprises (MNEs). Facing uncertainties and ambiguities prevalent in the Chinese business environment, more and more MNEs are turning to a strategic approach as the way forward. How MNEs choose an appropriate market-entry strategy has become an important issue. An accurate competitive strategy has positive effects on business performance (Kirca et al. 2005; Matsuno, Mentzer 2000; Olson et al. 2005; Strandskov 2006; Vorhies, Morgan 2003). Strategy is a pattern of resource allocation that enables firms to maintain or improve their per- 
formances (Barney 1997). The study of the core-competency concept for strategy formulation has generated enormous interest since it is an element of successful strategy for MNEs (Grant 1991; Hoskisson et al. 2004; Kak 2004; O’Tegan, Ghobadian 2004; Prahalad, Hamel 1990; Toni, Tonchia 2003). Core competency is a concept well known to academics, business practitioners, and consultants in strategic management. Wernerfelt (1984) argued that corporations constitute a combination of tangled and intangible resources rather than a combination of products and markets. He also portrayed "resource inventory" and "resource advantage" as highly meaningful components of strategic decision-making. Scholars have acknowledged the importance of core competency in formulating strategy (Grant 1991; Lahti 1999; O’Tegan, Ghobadian 2004; Toni, Tonchia 2003). Even though past research defined core-competency concepts from a multitude of viewpoints, all of those viewpoints are consistent with the perspective that core competencies lead to sustainable competitive advantage (Hafeez et al. 2002; Petts 1997; Prahalad, Hamel 1990; Korsakiene 2004; Ginevičius et al. 2010).

The biotech pharmaceutical industry has enormous opportunities to grow. Along with technology development in the pharmaceutical field, nowadays the importance of biotech pharmaceutical products continues to grow despite its considerable dimensions (Business Wire 2009). Wolff (2001) mentioned that the difference between biotechnology-derived drugs and conventional pharmaceuticals is profound but can be summed up in a single word: specificity. The biotech approach to drug development is based on detailed information about the operations of cells and molecules. Although this body of knowledge is far from complete, it has afforded biotech companies the ability to develop drugs that act in precise ways according to biological functions.

In China, the biotech pharmaceutical industry has been growing rapidly. A research report that appeared in China Research and Intelligence (2008) mentioned that in 2008, the market size of China's biotech pharmaceutical industry was about 70 billion Yuan (about US\$10 billion), with a growth rate exceeding in size not only the three sectors of chemical-medicine materials, chemical-medicine doses, and traditional Chinese prepared medicines, but indeed China's entire medicine market. Under the current global economic recession, however, the development of China's biotech pharmaceutical industry has exhibited impressive momentum. The market of China's biotech pharmaceutical industry has been gradually expanding because of such favorable factors as China's rapid economic growth, people's growing incomes, increased understanding of and demand for biotech pharmaceutical medicine, improvements in China's healthcare system, and people's rising awareness of disease treatment. Fig. 1 shows the market scale of the biotech pharmaceutical industry in China during the period stretching from 2003 to 2007 (China Research and Intelligence 2008).

Previous research targeting market-entry strategies, especially in the context of the biotech pharmaceutical industry, has focused on corporate-level strategy, such as joint ventures, strategic alliances, mergers and acquisitions, and licensing agreements (Brouthers 2002; Chen, Lou 2005; Deeds, Hill 1996; Richards, DeCarolis 2003; Shan, Song 1997). To our knowledge, no study focuses on competitive (business)-level strategy, which is 


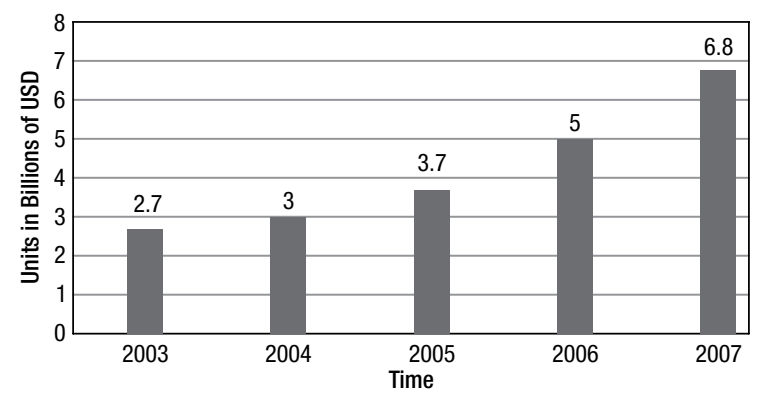

Fig. 1. Market scale of the biotech pharmaceutical industry in China (2003-2007)

the foundation of successful business. For a firm trying to establish itself internationally, choosing a strategy for entry into a foreign market is of crucial importance. Therefore, to fill the gap in the literature, the current study elaborates on how multinational biotech pharmaceutical enterprises that are willing to invest in, or are currently investing in and want to expand, their business select an appropriate competitive strategy to compete in China.

FDI is a complex multi-criteria decision-making problem (Devrim 2009; Hyun 2006; Weng et al. 2010). As criteria and alternatives increase, it is difficult for a human brain to analyze their relationships and make a rigorous decision. In this situation, it is necessary to use a technique that helps solve complex multi-criteria decision-making problems. Analytic network process (ANP), introduced by Saaty can account for objective and subjective evaluation criteria and dependence among alternatives or criteria. Moreover, decision makers facing these many complex relationships are usually unable to explicitly identify their preferences owing to uncertain judgments with internal inconsistency; indeed, decision makers often can express their own opinions only in linguistic terms. This overall difficulty makes fuzzy logic a more natural approach to such decision-making problems. Although ANP is a fine technique, it is insufficient in eliminating ambiguities. In order to overcome this shortcoming, researchers have used the fuzzy ANP method instead of classical ANP. This study uses fuzzy analytic network process (FANP) to construct a hierarchical model involving interactions among various factors for competitive-strategy selection based on the core-competency perspective. The findings not only identify important core competencies of FDI for competitive strategy and rank these competencies according to their importance, but also rank competitive strategies according to their level of competitiveness for decision makers.

The remainder of this paper is structured as follows. The second section presents a comprehensive review of the literature including core competency, the relationship between core competency and competitive strategy, and the ANP approach. The third section describes the current study's research process and introduces fuzzy numbers and research methodology as applied in this research. The empirical analysis and findings are discussed in Section 4. Section 5 concludes this paper and provides managerial implications. 


\section{Literature review}

\subsection{Core competency}

The resource-based perspective rests on an internal analysis of firms and suggests that firms are a collection of heterogeneous resources (tangible and intangible) that are semipermanently tied to a company (Wernerfelt 1984). These resources form an important source of competitive advantage for firms. Those core resources and core capabilities must be valuable, rare, imperfectly imitable, and non substitutable (Barney 1991). Core competency in a firm is an activity that is performed more successfully by the firm than by its competitors and that is in demand in the market. Specifically, the competency of a corporation is a combination of resources that are superior in competition under the whole strategy of the corporation (Collis, Montgomery 1995). Management writers have attributed varied meanings to the term "core competency" (or as alternatively worded "core competence"). Lei et al. (1996) defined a firm's core competencies as a set of problem-defining and problem-solving insights that fosters the development of idiosyncratic strategic growth alternatives. Markides and Williamson (1994) defined core competencies as a pool of experience, knowledge, and systems that together can act as catalysts for the creation and accumulation of new strategic assets. These strategic assets, which are imperfectly imitable, constitute a firm's competitive advantage. Petts (1997) defines core competencies as a unique combination of technologies, knowledge, and skills that are possessed by one company in a market. Prahalad and Hamel (1990) mention that core competencies reflect the specialized expertise of an organization resulting from the organization's collective learning. They propose a way to categorize core competencies, usefully distinguishing among three broad types: (1) Market-access competencies are skills that help place a firm in close proximity to its customers. Such skills include brand management, sales and marketing, distribution and logistics, and technical support. (2) Integrity-related competencies are skills that enable a firm to conduct its operations more quickly, with greater flexibility, or with a higher caliber of reliability than competitors. Such competencies concern such matters as quality, cycle time management, and just-in-time operations. And (3) functionality-related competencies are skills that enable the firm to invest its services or products with unique functionality-that is, to endow the product with distinctive customer benefits, rather than merely make it incrementally better than competitors' products.

Bogner et al. (1996) analyzed the 41 largest pharmaceutical firms in the United States and Western Europe in terms of their core competencies and looked at how the relative competitive postures of these firms changed in the US market between 1969 and 1988. Kak (2004) explored a case study of two pharmaceutical organizations to investigate the issues related to core-competency development and strategy formulation with core competency. The findings revealed that the core competencies in Eli Lilly \& Company, a worldwide leader in pharmaceuticals, were R \& D and marketing, whereas the core competencies of another global pharmaceutical company, Pharmacia \& Upjohn, were R \& D and dedicated manpower. Another study narrowed its focus on biotech pharmaceuticals and emphasized the future importance of R \& D leadership for this industry (Feltz 2007). Powell, Brantley (1992) suggested that firms in a wide range of industries 
were executing nearly every step in the production process through some form of external collaboration. These researchers argued that biotechnology firms were opting to sustain - by means of vertical integration - their competitive ability to learn through interdependence rather than through independence. With the growing complexity of process development, R \& D firms like Pfizer have come to realize that they need to collaborate with other organizations that have expertise (Mehta, Peters 2007). Liu and Cheng (2000) pointed out that the entry strategies in China for pharmaceuticals may involve more complicated considerations: government policies (including legislation, healthcare insurance, medical insurance, regulatory affairs, and distribution), brand position, corporate strategies (consisting of target segments, marketing, spending, market channels, and prices), product life cycle, order of entry, and product category.

\subsection{Competitive (business) strategy}

In the world of business, strategy is a way by which a firm fulfills its mission and attains its objectives. Brandenburger and Stuart (1996) mentioned that the essence of strategy lies in creating favorable asymmetries between a firm and its rivals. According to Barney (1997), strategy is a pattern of resource allocation that enables firms to maintain or improve their performances. A good strategy neutralizes threats, exploits opportunities, capitalizes on strengths, and fixes weaknesses. The hierarchical view of strategy visualizes at least three levels of strategies. First, within large multi-business corporations, corporate strategy involves the selection of product markets or industries and the allocation of resources among them. Corporate-strategy decisions include investment in diversification, vertical integration, acquisitions, and new ventures. Second, competitive (business) strategy is concerned with how the firm competes within a particular industry or market. What business or businesses should we be in (corporate strategy) and how should we conduct ourselves strategically within each business? How should we compete (against competitors, for targeted customers, to sustain performance)? Each business unit within a multi-business corporation could have its own specially tailored competitive (business) strategy designed to strengthen the individual business uits' use of distinctive competencies as competitive weapons. Third, functional strategies are the elaboration and implementation of competitive (business) strategies through individual functions such as production, $\mathrm{R} \& \mathrm{D}$, marketing, human resources, and finance. They are primarily the responsibility of the functional departments (Bernard 2010; Swamidass, Newell 1987).

There are various approaches to follow to formulate a competitive strategy. Several strategic typologies have been proposed in the strategic-management literature over the years. Barczak (1995) suggested three strategic types based on the timing of entry, the first-to-market scenario, the fast-follower scenario, and the delayed-entrant scenario. Miles and Snow (1978) postulated four strategic types: defenders, prospectors, analyzers, and reactors. Porter (1980) described typology consisting of three general types of strategies (cost leadership, differentiation, and focus) that businesses commonly use to achieve and maintain competitive advantage. These strategies are applied at the business-unit level, and they are not firm or industry dependent. 
Product differentiation fulfills a unique customer need by tailoring the product or service, allowing organizations to charge a premium price to capture market share. The differentiation strategy is implemented effectively when the business provides unique or superior value to the customer through product quality, features, or after-sale support. Firms following a differentiation strategy can charge a higher price for their products on the basis of product characteristics, delivery system, quality of service, or distribution channels. Spanos and Lioukas (2001) argued that there are at least two types of differentiation strategies. One is based on innovation differentiation, whose function is to make possible the most advanced and attractive products regarding the novelty of their quality, efficiency, design, or style. The other is based on marketing differentiation, whose function is to create a unique image for a product through marketing practices. Lower costs and cost advantages result from process innovations, learning-curve benefits, economies of scale, reductions, product designs that reduce manufacturing time and costs, and reengineering activities. Low-cost leadership strategy requires a vigorous pursuit of cost reductions deriving from experience, tight cost and overhead controls, avoidance of managerial customer accounts, and cost minimization in all activities, such R \& D, advertising, process innovation, and product development. This strategy is implemented effectively when the firm designs, produces, and markets a product more efficiently than competitors. The focus is also known as a "niche" strategy, wherein the firm concentrates on a narrow competitive scope within the industry. Firms that succeed in a "focus strategy" are able to tailor a broad range of product-development strengths to a relatively narrow market segment that they know very well. Focus strategies grow market share by operating in a niche market or markets not attractive to, or overlooked by, larger competitors. A successful focus strategy needs an industry segment large enough to have good growth potential but not of key importance to major competitors. Firms may use a focus strategy in conjunction with either the cost or differentiation strategies in a specific market niche (Allen et al. 1999).

\subsection{The relationship between core competency and strategy formulation}

Researchers have developed the concept of core competency to support more efficient identification and use of organizations' strength. In the business world, the nature of firms' existing resources determines whether the firms need to engage in such resource augmentation when investing abroad (Meyer et al. 2009). Scholars have acknowledged the importance of core competency in formulating strategy.

Hoskisson et al. (2004) suggested that capabilities, whether existing or potential, influence strategic decision-making. With the successful development of resource-based theory, the focus of corporate-strategy analysis has shifted from external-context factors to internal-resource factors. The importance of internal evaluation is the general lesson that corporate strategy should be guided by internal resources and competency (Grant 1991). Toni and Tonchia (2003) and Grant (1991) argued that, from one point of view, resources constitute the source of a firm's competitive advantage and that, from another point of view, resources define a firm's strategic direction. Lado and Wilson (1994) stated that identification of core competency has centered not only on materializing corporate-strategy intent but also on triggering the related management activities in pur- 
suit of competitive advantages. O'Tegan and Ghobadian (2004) characterized strategybased resources as a key factor in developing strategy. A firm formulates a strategy that establishes a bridge from the firm's internal resources and skills to the opportunities and risks created by the external environment. While formulating the strategy, the firm highlights its core competencies and privileges them in order to extract from them the greatest benefits. The failure of managers to deal effectively with core-competency issues is the main cause of strategic oversights (Kak 2004). The core-competency model is a corporate-strategy model that starts the strategy-development process by getting people to think about the core strengths of an organization (Prahalad, Hamel 1990).

\subsection{ANP approach}

The analytic hierarchy process (AHP) is a powerful tool for dealing with complex multicriteria decision-making problems, which helps to establish decision models which takes both qualitative and quantitative components into consideration. The AHP helps analysts to organize the critical aspects of a problem into a hierarchy rather like a family tree. By reducing complex decisions to a series of simple comparisons and rankings, then synthesizing the results, the AHP not only helps the analysts to arrive at the best decision, but also provides a clear rationale for the choices made (Karimi et al. 2011). After proposing by Saaty (1980), it has been applied in a variety of fields. Whereas AHP represents a framework with unidirectional relationships among elements of the system, which implies there is no impact of lower levels on the upper levels. A hierarchical model therefore is not appropriate for a complex system involving interaction among various factors. Analytic network process (ANP) is then developed for filling this gap.

ANP also introduced by Saaty (1996) is the generic form of AHP. ANP does not require hierarchical structure, because it replaces the hierarchy in the AHP with a network incorporating feedback and interdependent relationships among elements. Not only does the importance of the criteria determine the importance of the alternatives as in a hierarchy, but also the importance of the alternatives may have impact on the importance of the criteria (Saaty 1996, 2006). ANP provides a general framework for dealing with decisions without generating assumptions about the independence between levels of a hierarchy (Saaty 2005).

The object herein is to select the best entry strategy from alternatives for biotech pharmaceutical firms. The problem becomes complex due to numerous criteria that have interactions between and within each other. It is not easy to analyze most amount of criteria correctly. Therefore, it is necessary to need a technique combining both qualitative and quantitative information. It seems appropriate to use ANP as analytic tool for location selection because of its suitability in providing solutions in such a complex multi-criteria decision environment.

Human beings do not have enough ability to make decision since the problem is too complex to be understood. They often find solutions by rules of thumb or heuristic thinking based on binary logic. However, real life is full of uncertainty by its characteristic with nature. The results obtained by evaluating a situation or a system related particularly with human factor and human thought from a certain and absolute perspective 
prove inadequate in reflecting the reality (Sen 2001, 2003). Therefore, fuzzy logic with fuzzy numbers is involved into the process of human judgment to eliminate vagueness, subjectivity and imprecision. Mikhailov and Singh (1999) conducted a comparative study on traditional crisp values and fuzzy intervals, and found that fuzzy measures perform better than crisp values. This study applies fuzzy ANP to solve problem in selecting competitive strategy in China. One of reasons for using fuzzy application is that it gives us the most truthful results.

\subsection{Summary}

In this study, we held a focus-group discussion (FGD) with eight experts to determinefollowing the aforementioned literature and the characteristics of the biotech pharmaceutical industry-preliminary core competencies that influence China-based multinational biotech pharmaceutical enterprises' strategy selection relative to FDI. The preliminary core competencies are comprehensive factors involving international-strategy decisions. But resources are not always linked to a core competency. Not all determinants are relevant for each enterprise; there may be only a few important factors, and they would dominate the decision-making processes in each business (Stevenson 1996). The current study also accounts for Porter's (1980) approach to generating preliminary competitive strategies because his typology is similar to others' and has received more empirical support from previous research than other typologies.

\section{Fuzzy numbers and research method}

\subsection{Fuzzy numbers}

As mentioned above, human beings are often unable to make rigorous judgments because of the complexity of the matter at hand. Traditional multiple-attribute decisionmaking methods cannot effectively handle problems characterized by imprecision and vagueness. To resolve this issue, Zadeh (1965) introduced fuzzy set theory, which served to illustrate the fuzzy phenomena occurring in human activities. The theory's function was to convert human behaviors and conceptual languages into fuzzy numbers using the uncertain elements of fuzzy set membership (Lee et al. 2011). Van Laarhoven and Pedrycz (1983) showed that these fuzzy numbers can be calculated and ranked.

The fuzzy sets are defined in terms of membership functions. Membership functions relative to $\mathrm{X}$ represent fuzzy subsets of $\mathrm{X}$. The membership function representing a fuzzy set is usually denoted by $\mu_{A}$. For an element $x$ of $X$, the value $\mu_{A}(x)$ is called the membership degree of $x$ in the fuzzy set. This function assigns to each element $\mathrm{x}$ of the universal set $\mathrm{X}$ a number $\mu_{A}(x)$ in the unit interval $[0,1]$. The membership degree $\mu_{A}(x)$ quantifies the grade of membership of the element $x$ to the fuzzy set. An element $x$ really belongs to $\mathrm{A}$ if $\mu_{A}(x)=1$ and clearly does not if $\mu_{A}(x)=0$.

A triangular fuzzy number can be denoted by three real numbers $(l, m, u)$. The parameters $l, m$, and $u$ respectively stand for the smallest possible value, the most promising value, and the largest possible value. Its membership function can be defined as 


$$
(d)=\left\{\begin{array}{ll}
1, & \text { if } m_{2} \geq m_{1}, \\
0, & \text { if } l_{1} \geq u_{2}, \\
\frac{l_{1}-u_{2}}{\left(m_{2}-u_{2}\right)-\left(m_{1}-l_{1}\right)}, & \text { otherwise, }
\end{array}\right\} .
$$

Detailed definitions and discussions of the arithmetic operations pertaining to triangular fuzzy numbers can be found in Dubois and Prade (1978), Giachetti and Young (1997), Kaufmann and Gupta (1988), Wagenknecht et al. (2001), Kahraman et al. (2002), and Zadeh (1965).

\subsection{Research method}

Chang's method has been applied in this study. Let $X=\left\{x_{1}, x_{2}, \ldots, x_{n}\right\}$ be an object set, and $U=\left\{u_{1}, u_{2}, \ldots, u_{n}\right\}$ be a goal set. According to Chang's extent-analysis method $(1992 ; 1996)$, each object is taken and an extent analysis for each goal $\left(\mathrm{g}_{i}\right)$ is performed. Therefore, $m$ extent analysis values for each object can be obtained with the following signs:

$$
M_{g_{i}}^{1}, M_{g_{i}}^{2}, \ldots, M_{g_{i}}^{m}, \quad i=1,2, \ldots, n,
$$

where all the $M_{g_{i}}^{j}(j=1,2, \ldots, n)$ are TFNs. The steps of Chang's extent analysis can be given as in the following:

Step 1: The value of fuzzy synthetic extent with respect to the $i^{\text {th }}$ object is defined as

$$
S_{j}=\sum_{j=1}^{m} M_{g_{i}}^{j} \otimes\left[\sum_{i=1}^{n} \sum_{j=1}^{m} M_{g_{i}}^{j}\right]^{-1}
$$

To obtain $\sum_{j=1}^{m} M_{g_{i}}^{j}$, perform the fuzzy addition operation of $m$ extent analysis relative to values for a particular matrix such that

and to obtain $\left[\sum_{i=1}^{n} \sum_{j=1}^{m} M_{g_{i}}^{j}\right]^{-1}$, perform the fuzzy addition operation of $M_{g_{i}}^{j}(j=1,2, \ldots, m)$

$$
\sum_{j=1}^{m} M_{g_{i}}^{j}=\left(\sum_{j=1}^{m} l_{j}, \sum_{j=1}^{m} m_{j}, \sum_{j=1}^{m} u_{j}\right)
$$

values such that

$$
\sum_{i=1}^{n} \sum_{j=1}^{m} M_{g_{i}}^{j}=\left(\sum_{j=1}^{m} l_{i}, \sum_{j=1}^{m} m_{i}, \sum_{j=1}^{m} u_{i}\right)
$$

and then compute the inverse of the vector in Eq. (4) such that

$$
\left[\sum_{i=1}^{n} \sum_{j=1}^{m} M_{g_{i}}^{j}\right]^{-1}=\left(\frac{1}{\sum_{i=1}^{n} u_{i}}, \frac{1}{\sum_{i=1}^{n} m_{i}}, \frac{1}{\sum_{i=1}^{n} l_{i}}\right) .
$$

Step 2: The degree of the possibility of $M_{2}=\left(l_{2}, m_{2}, u_{2}\right) \geq M_{1}\left(l_{1}, m_{1}, u_{1}\right)$ is defined as $V\left(M_{2} \geq M_{1}\right)=\sup _{y \geq x}\left[\min \left(u_{M_{1}}(x), u_{M_{2}}(y)\right)\right]$ 
and can be equivalently expressed as follows:

$$
V\left(M_{2} \geq M_{1}\right)=\operatorname{hgt}\left(M_{1} \cap M_{2}\right)=u_{M_{2}}(d)=\left\{\begin{array}{ll}
1, & \text { if } m_{2} \geq m_{1}, \\
0, & \text { if } l_{1} \geq u_{2}, \\
\frac{l_{1}-u_{2}}{\left(m_{2}-u_{2}\right)-\left(m_{1}-l_{1}\right)}, & \text { else, }
\end{array}\right\},
$$

where $\mathrm{d}$ is the ordinate of the highest intersection point $\mathrm{D}$ between $u_{M_{1}}$ and $u_{M_{2}}$. To compare $\mathrm{M}_{1}$ and $\mathrm{M}_{2}$, we need both the values of $V\left(M_{1} \geq M_{2}\right)$ and $V\left(M_{2} \geq M_{1}\right)$. This is given in Fig. 2.



Fig. 2. Intersection of $M_{1}$ and $M_{2}$

Step 3: The degree possibility for a convex fuzzy number to be greater than $k$ convex fuzzy numbers $M_{\mathrm{i}}(i=1,2, \ldots, k)$ can be defined by $V\left(M \geq M_{1}, M_{2}, \ldots, M_{k}\right)=V\left[\left(M \geq M_{1}\right) v e\left(M \geq M_{2}\right)\right.$ and...and $\left.\left(M \geq M_{k}\right)\right]=$ $\min V\left(M \geq M_{i}\right), \quad i=1,2, \ldots, k$.

Assume that

$d^{\prime}\left(A_{i}\right)=\min V\left(S_{i} \geq S_{k}\right)$.

For $k=1,2, \ldots, n ; \mathrm{k} \neq i$. Then the weight vector is given by $W^{\prime}=\left(d^{\prime}\left(A_{1}\right), d^{\prime}\left(A_{2}\right), \ldots, d^{\prime}\left(A_{n}\right)\right)^{T}$, where $A_{i}(i=1,2, \ldots, n)$ are $n$ elements.

Step 4: Via normalization, the normalized weight vectors are $W=\left(d\left(A_{1}\right), d\left(A_{2}\right), \ldots, d\left(A_{n}\right)\right)^{T}$, where $W$ is a nonfuzzy number.

\subsection{The proposed research process for selecting the best competitive strategy alternative}

The research process of this study is divided into four steps, as presented in Fig. 3, and these steps are described in the following section. 


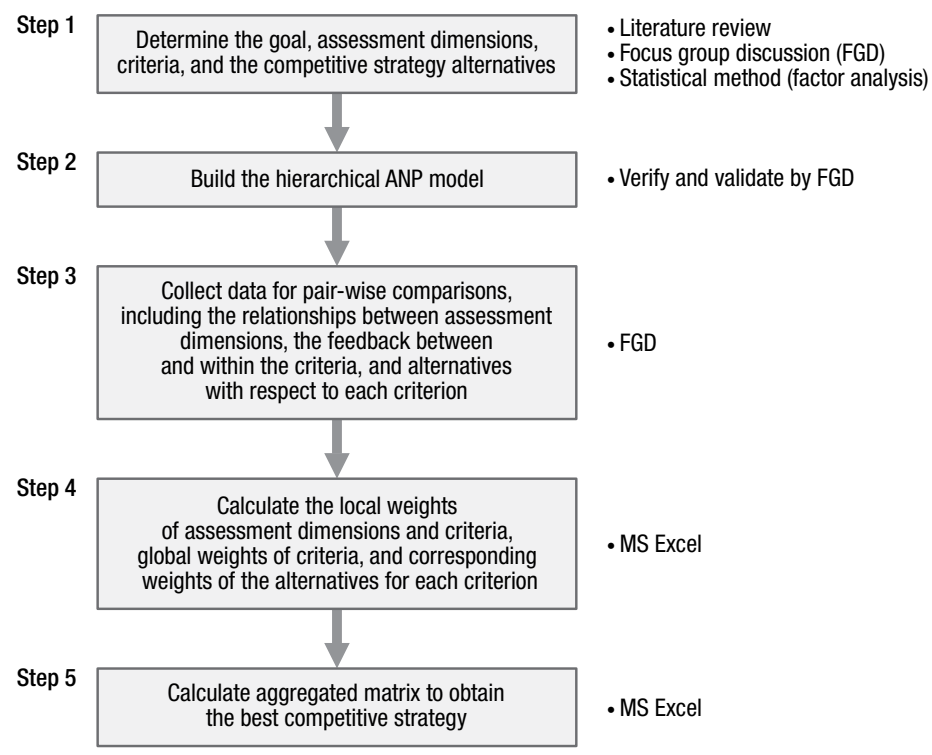

Fig. 3. The proposed research process for selecting the best competitive strategy alternative

\section{Proposed model implementation}

\subsection{Structuring the hierarchical model of the selection of the competitive strategy, including goal, assessment dimension, criteria, and alternatives}

First, this study determines the goal as the selection of the most suitable competitive strategy by FGD with 8 experts. Most of the experts had more than 16 years of experience in the identified pharmaceutical company, and had roles as marketing \& sales director, general manager, and manager. The study then identifies the criteria and categorizes them according to (1) a literature review and (2) experts who got involved in this study to finalize, verify, and validate the criteria. A total of 100 questionnaires were sent to specialists in biotech pharmaceutical companies in China and Taiwan, and 56 valid samples were returned, the valid questionnaire rate being about $60 \%$.

The results from Kaiser-Meyer-Olkin's measure of sampling adequacy and Bartlett's test for sphericity indicate that 14 assessment criteria are suitable for factor analysis. For this study, we used factor analysis based on empirical data to identify items with low factor loading, reconfirming and deleting by FGD. Finally, we decided on 12 criteria and classified them into three assessment dimensions: the relationship dimension, the tactic dimension and the specificity dimension. Also, considering Porter's generic strategies, selected three: differentiation strategy and focus strategies including innovative focus strategy and market focus strategy as our competitive strategy alternatives. The expert team doesn't take low-cost strategy into considerations since it is not easy for firms invested in China to compete with local ones on cost basis due to the lack of protection for intellectual property rights and the prevailence of biogenerics. The model for competitive strategy selection with symbol definitions is proposed in Fig. 4. 
Y.-H. Lee. A fuzzy analytic network process approach to determining prospective competitive strategy in China ...

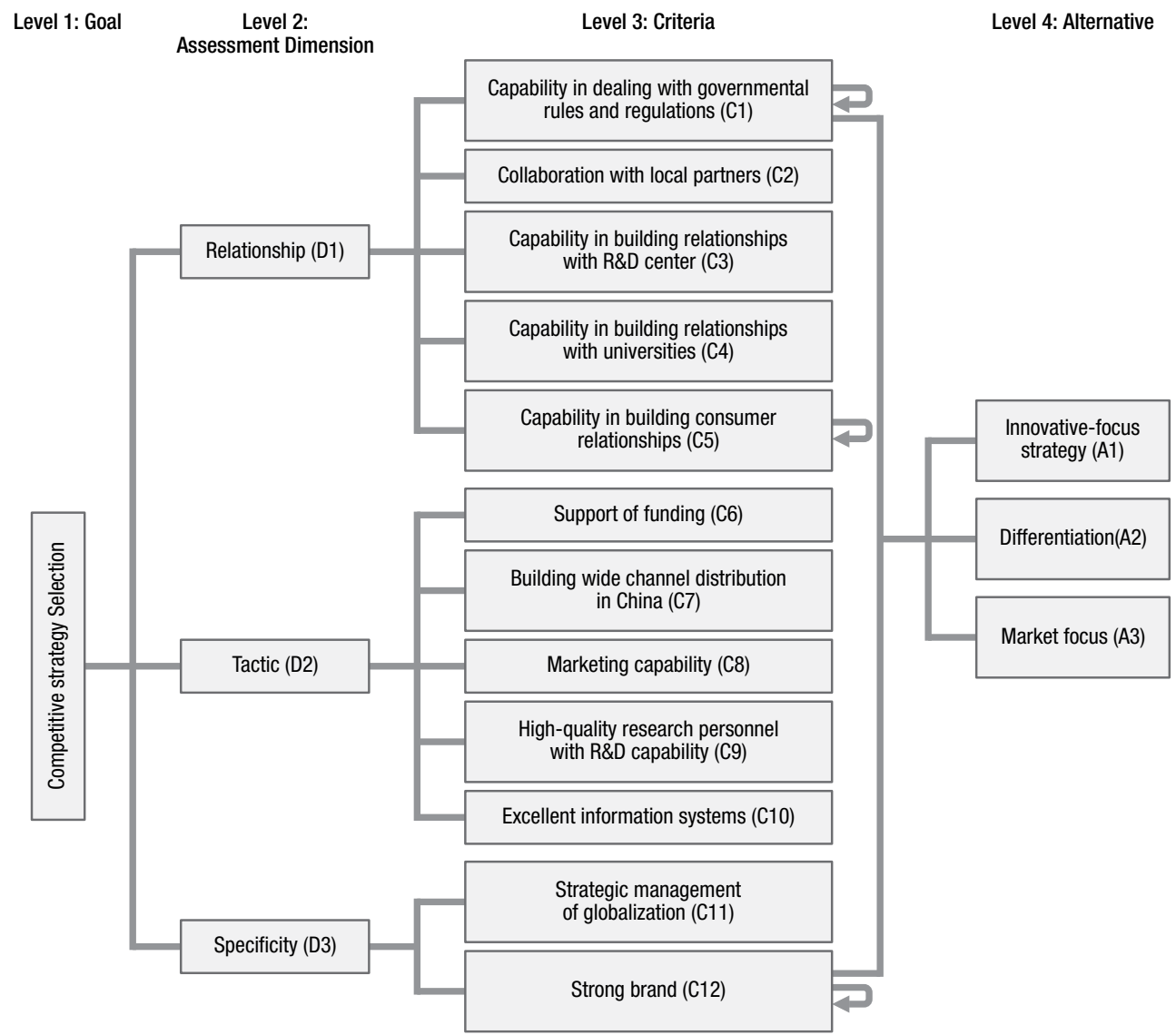

Fig. 4. A hierarchical model for business-strategy selection

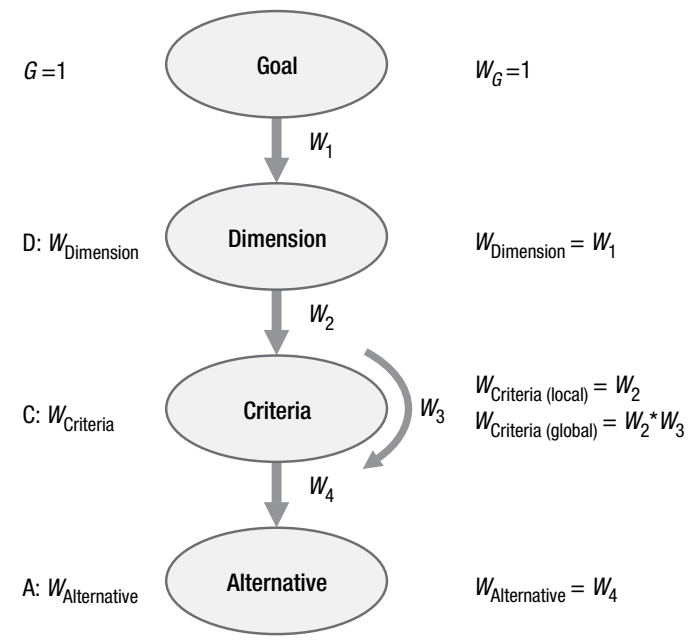

Fig. 5. The network with symbols 
The hierarchical model depicts a situation where there is no interaction among the dimensions, while the loop diagram indicates a situation where there is interaction between criteria. Fig. 5 shows the network with representative symbols. Appendix presents the corresponding detailed definitions.

\subsection{Calculating the local weights of assessment dimensions with respect to the goal}

In this step, three assessment dimensions are compared to each other with respect to goal. The pair-wise comparisons rest on FGD (with a scale ranging from 1 through 9) and on geometric mean method, then pair-wise comparison matrices are formed with a fuzzy scale. The fuzzy scale regarding relative importance to measure the relative weights can be seen in Table 1. With fuzzy values, we obtain weights of each assessment dimension as shown in Table 2.

Table 1. Linguistic scales for the importance weight

\begin{tabular}{ccc}
\hline Linguistic scales for importance degree & Linguistic terms & Linguistic values \\
\hline 1 & Equal importance (EI) & $(1,1,2)$ \\
\hline 3 & Moderate importance (MI) & $(2,3,4)$ \\
\hline 5 & Strong importance (SI) & $(4,5,6)$ \\
\hline 7 & Very strong importance (VI) & $(6,7,8)$ \\
\hline 9 & Absolute importance (AI) & $(8,9,9)$ \\
\hline 2 & Intermediate values & $(1,2,3)$ \\
\hline 4 & & $(3,4,5)$ \\
\cline { 3 - 4 } & & $(5,6,7)$ \\
\hline 6 & & $(7,8,9)$ \\
\hline
\end{tabular}

Table 2. Pair-wise comparison matrix and weights of assessment dimensions

\begin{tabular}{ccccc}
\hline Dimensions & D1 & D2 & D3 & Weights \\
\hline D1 & $(1,1,1)$ & $(2.37,2.69,3.12)$ & $(2.93,3.44,4.15)$ & 0.52 \\
\hline D2 & $(1.79,2.35,2.75)$ & $(1,1,1)$ & $(2.65,3.37,3.99)$ & 0.47 \\
\hline D3 & $(1.03,1.39,1.62)$ & $(1.34,1.67,2.04)$ & $(1,1,1)$ & 0.01 \\
\hline
\end{tabular}

\subsection{Calculating the global weights of each criteria}

In this step, criteria's local weights in each assessment dimension are determined in the same way. Table 3 to Table 5 present the respective weights of the 12 criteria with respect to assessment dimensions. Moreover, the FGD serve to identify the inner loops among the criteria in each dimension. There are relations between the criteria in the relationship dimension, the tactic dimension and the specificity dimension. Table 6 to Table 8 presents the interdependent matrix of the inner relationships among criteria. 
Y.-H. Lee. A fuzzy analytic network process approach to determining prospective competitive strategy in China ...

Table 3. Pair-wise comparison matrix and weights under the Relationship Dimension

\begin{tabular}{lcccccc}
\hline D1 & C1 & C2 & C3 & C4 & C5 & Weights \\
\hline C1 & $(1,1,1)$ & $(1.14,1.45,2.28)$ & $(2.82,3.52,4.43)$ & $(2.92,3.62,4.53)$ & $(1.62,1.92,2.83)$ & 0.362 \\
\hline C2 & $(0.923,1.41,1.68)$ & $(1,1,1)$ & $(2.90,3.50,4.50)$ & $(2.80,3.40,4.30)$ & $(1.24,1.45,2.27)$ & 0.34 \\
\hline C3 & $(0.63,0.86,1.00)$ & $(0.31,0.53,0.58)$ & $(1,1,1)$ & $(1.21,1.52,2.42)$ & $(0.80,1.03,1.59)$ & 0.04 \\
\hline C4 & $(0.97,1.35,1.70)$ & $(0.32,0.55,0.60)$ & $(0.88,1.31,1.48)$ & $(1,1,1)$ & $(0.63,0.77,1.26)$ & 0.003 \\
\hline C5 & $(0.76,1.17,1.30)$ & $(1.04,1.56,1.78)$ & $(1.90,2.58,3.10)$ & $(2.18,2.94,3.55)$ & $(1,1,1)$ & 0.26 \\
\hline
\end{tabular}

Table 4. Pair-wise comparison matrix and weights under the Tactic Dimension

\begin{tabular}{ccccccc}
\hline D2 & C6 & C7 & C8 & C9 & C10 & Weights \\
\hline C6 & $(1,1,1)$ & $(1.29,1.61,2.15)$ & $(0.69,0.81,1.34)$ & $(1.04,1.25,2.06)$ & $(1.07,1.29,2 . .03)$ & 0.14 \\
\hline C7 & $(2.26,2.88,3.30)$ & $(1,1,1)$ & $(1.37,1.59,2.33)$ & $(1.50,1.70,2.70)$ & $(2.23,2.63,3.55)$ & 0.36 \\
\hline C8 & $(2.23,2.93,3.45)$ & $(1.09,1.65,1.97)$ & $(1,1,1)$ & $(1.43,1.73,2.65)$ & $(2.03,2.53,3.45)$ & 0.37 \\
\hline C9 & $(1.05,1.57,1.80)$ & $(0.44,0.85,0.86)$ & $(0.57,0.99,1.13)$ & $(1,1,1)$ & $(1.54,1.85,2.67)$ & 0.09 \\
\hline C10 & $(1.10,1.66,1.98)$ & $(0.53,0.90,1.06)$ & $(0.50,0.84,1.01)$ & $(1.01,1.48,1.72)$ & $(1,1,1)$ & 0.04 \\
\hline
\end{tabular}

Table 5. Pair-wise comparison matrix and weights under the Specificity Dimension

\begin{tabular}{cccc}
\hline D3 & C11 & C12 & Weights \\
\hline C11 & $(1,1,1)$ & $(1.06,1.38,2.12)$ & 0.46 \\
\hline C12 & $(1.18,1.71,2.05)$ & $(1,1,1)$ & 0.54 \\
\hline
\end{tabular}

Table 6. The weight matrix of inner dependence for criteria under the Relationship Dimension

\begin{tabular}{cccccc}
\hline $\mathrm{D} 1$ & $\mathrm{C} 1$ & $\mathrm{C} 2$ & $\mathrm{C} 3$ & $\mathrm{C} 4$ & $\mathrm{C} 5$ \\
\hline $\mathrm{C} 1$ & 1.00 & 0.00 & 0.00 & 0.00 & 0.00 \\
\hline $\mathrm{C} 2$ & 0.00 & 1.000 & 0.85 & 0.86 & 0.51 \\
\hline $\mathrm{C} 3$ & 0.00 & 0.00 & 0.153 & 0.00 & 0.00 \\
\hline $\mathrm{C} 4$ & 0.00 & 0.00 & 0.00 & 0.14 & 0.00 \\
\hline $\mathrm{C} 5$ & 0.00 & 0.00 & 0.00 & 0.00 & 0.49 \\
\hline
\end{tabular}

Table 7. The weight matrix of inner dependence for criteria under the Tactic Dimension

\begin{tabular}{cccccc}
\hline D2 & C6 & C7 & C8 & C9 & C10 \\
\hline C6 & 0.28 & 0.00 & 0.00 & 0.00 & 0.00 \\
\hline C7 & 0.00 & 0.29 & 0.33 & 0.00 & 0.00 \\
\hline C8 & 0.00 & 0.35 & 0.36 & 0.00 & 0.00 \\
\hline C9 & 0.66 & 0.30 & 0.31 & 1.00 & 0.96 \\
\hline C10 & 0.06 & 0.06 & 0.00 & 0.00 & 0.04 \\
\hline
\end{tabular}


Table 8. The weight matrix of inner dependence for criteria under the Specificity Dimension

\begin{tabular}{ccc}
\hline $\mathrm{D} 3$ & $\mathrm{C} 11$ & $\mathrm{C} 12$ \\
\hline $\mathrm{C} 11$ & 0.26 & 0.00 \\
\hline $\mathrm{C} 12$ & 0.75 & 1.00 \\
\hline
\end{tabular}

Finally, the global weight of each criterion is calculated by multiplying the local weight of each criterion with the corresponding aggregated interdependent matrix for each criterion. Take the global weights for $\mathrm{C}_{1}-\mathrm{C}_{5}$ as an example, the equation of which is as follows:

$$
w_{C_{1}-C_{5}}=\left[\begin{array}{ccccc}
1.00 & 0.00 & 0.00 & 0.00 & 0.00 \\
0.00 & 1.00 & 0.86 & 0.86 & 0.51 \\
0.00 & 0.00 & 0.15 & 0.00 & 0.00 \\
0.00 & 0.00 & 0.14 & 0.14 & 0.00 \\
0.00 & 0.00 & 0.00 & 0.00 & 0.49
\end{array}\right]\left[\begin{array}{l}
0.36 \\
0.34 \\
0.04 \\
0.003 \\
0.26
\end{array}\right]=\left[\begin{array}{l}
0.36 \\
0.50 \\
0.01 \\
0.01 \\
0.13
\end{array}\right] .
$$

Multiplying the global weight of each criterion with the corresponding weight of the assessment dimension yields the computed results for all criteria (see the last column in Table 9). There are three categories of data concerning ranked importance: Collaboration with local partners $(\mathrm{C} 1)$, Governmental rules and regulations (C2) and High-quality research personnel with $\mathrm{R} \& \mathrm{D}$ capability (C9).

Table 9. The computed results for all criteria

\begin{tabular}{cccc}
\hline Assessment Dimension & Criteria & Global Weight & Computed Result \\
\hline Relationship (0.52) & C1 & 0.362 & 0.189 \\
\hline & C2 & 0.505 & 0.263 \\
\hline & C3 & 0.006 & 0.003 \\
\hline Cactic $(0.47)$ & C5 4 & 0.006 & 0.003 \\
\hline & C6 & 0.126 & 0.067 \\
\hline & C7 & 0.039 & 0.018 \\
\hline Cpecificity $(0.01)$ & C9 & 0.227 & 0.106 \\
\hline & C10 & 0.257 & 0.120 \\
\hline & C11 & 0.445 & 0.209 \\
\hline & C12 & 0.032 & 0.015 \\
\hline
\end{tabular}




\subsection{Comparing the competitive strategy alternatives with respect to criteria under each assessment dimension}

After obtaining the local weights for each assessment dimension and global weights for each criterion, it is necessary to compare the competitive strategy alternatives with respect to each criterion. Table 10 presents the fuzzy weights of the alternatives under each criterion.

Table 10. Fuzzy weights of the alternatives under each criterion

\begin{tabular}{cccc}
\hline Criteria & \multicolumn{3}{c}{ Alternatives } \\
\cline { 2 - 4 } & A1 & A2 & A3 \\
\hline C1 & 0.323 & 0.591 & 0.085 \\
\hline C2 & 0.447 & 0.155 & 0.398 \\
\hline C3 & 0.362 & 0.381 & 0.257 \\
\hline C4 & 0.482 & 0.409 & 0.109 \\
\hline C5 & 0.599 & 0.167 & 0.234 \\
\hline C6 & 0.043 & 0.529 & 0.428 \\
\hline C7 & 0.540 & 0.000 & 0.460 \\
\hline C8 & 0.691 & 0.083 & 0.226 \\
\hline C9 & 0.385 & 0.302 & 0.314 \\
\hline C10 & 0.440 & 0.088 & 0.472 \\
\hline C11 & 0.459 & 0.250 & 0.291 \\
\hline C12 & 0.586 & 0.407 & 0.007 \\
\hline
\end{tabular}

\subsection{Obtaining the best competitive strategy alternative}

In this step, the final weights of "competitive strategy" alternatives are calculated. By multiplying the values in Table 10, with the global weight of each criterion, we obtain the priorities for the competitive strategy (Table 11). Innovative strategy is the best competitive strategy with a 0.455 value. The remaining two rankings of the alternatives are market focus strategy and differentiation strategy. Take the Tactic dimension (D2) as an example.

$$
W_{D 2}=\left[\begin{array}{lllll}
0.043 & 0.541 & 0.691 & 0.385 & 0.440 \\
0.529 & 0.000 & 0.083 & 0.302 & 0.088 \\
0.428 & 0.460 & 0.226 & 0.314 & 0.472
\end{array}\right]\left[\begin{array}{l}
0.018 \\
0.106 \\
0.120 \\
0.209 \\
0.015
\end{array}\right]=\left[\begin{array}{l}
0.228 \\
0.084 \\
0.156
\end{array}\right] .
$$


Table 11. Results of competitive strategy alternatives

\begin{tabular}{cccc}
\hline Dimension & \multicolumn{3}{c}{ Alternative } \\
\cline { 2 - 4 } & A1 & A2 & A3 \\
\hline D1 & 0.221 & 0.166 & 0.138 \\
\hline D2 & 0.228 & 0.084 & 0.156 \\
\hline D3 & 0.006 & 0.004 & 0.0004 \\
\hline Sum & 0.455 & 0.254 & 0.294 \\
\hline
\end{tabular}

\subsection{Discussion}

This study presents an effort to select the most suitable competitive strategy for multinational biotech pharmaceutical enterprises. The obtained results reveal that innovative strategy comes in at the top of the rankings.

There are three types of medicinal drugs in China. One is brand-name drugs, which rely on their trade-based reputation and which hold patents on the drugs (the drugs can be produced and sold only by the company holding the patent). The second is off-patent drugs, which are produced by a brand-name company after the patents' expiration. The third is generic drugs, which are former brand-name drugs that, owing to the expiration of their patent and to government approval, appear on the market as generic drugs sold by non-"brand name" companies. Of the Chinese domestic biotech pharmaceutical market, $97 \%$ is made up of biogenerics. On average, for each patent-expired drug, more than 100 generic-drug manufacturers reproduce and sell the product. Generic drugs marketed without brand names are usually less expensive than brand-name drugs. In particular, once there are over five generic manufacturers, the average price of the generic drug drops below $30 \%$ of the brand-name drug price. On the other hand, because most China-based biotech pharmaceutical enterprises are small and medium-size enterprises (SMEs), it is difficult to invest significant sums of money in new-drug innovation, particularly given the risk of disappointing results stemming from long-term drug-development research. Other obstacles to the development of innovative medicines are insufficient pharmaceutical-based research personnel, unsatisfactory government incentives extended to the pharmaceutical industry, and pharmaceuticals' shortage of capital. By contrast, biotech pharmaceutical multinational enterprises possess abundant funding, competitive power, R \& D capability, sufficient dedicated manpower, and a willingness to make investments and to take a high degree of risk. The investment and risk that these enterprises shoulder reflect their acknowledgment that successful biotech pharmaceuticals, when operating as multinationals, must identify and develop and bring to market novel drugs. Therefore, it is reasonable to argue that innovation-oriented strategies are the best type of competitive strategy by which MNEs can best avoid highrivalry density and earn a profit.

Drug development is extremely time-consuming and costly. No single organization has all the expertise necessary to produce the medical innovations that customers want. 
Therefore, MNEs that collaborate with useful entities on the domestic front (i.e., that form strategic alliances with complementing resources in the host country) will gain access to new research capabilities, accelerate products' introduction time (thereby granting first-mover advantage to the MNEs), and reduce the risk of incurring fruitless and unnecessarily expensive research and development costs. To progress beyond incremental improvements, biotech pharmaceutical enterprises should not only continuously cultivate internal expertise but also collaborate with partners whose capabilities augment its own. Such collaborations enable a biotech pharmaceutical enterprises to strengthen its entire R \& D value chain (Kak 2004). Furthermore, MNEs' cooperation with local partners can accelerate the MNEs' entrance into the Chinese market, thereby enabling the MNEs to overcome obstacles related to cultural, language, geographical, and political barriers. In addition, China's business environment is highly volatile, and China itself is a complex set of markets, especially regarding rules and regulations. For example, China has strict legislation governing investment protocol, patent-acquisition, drug-pricing, public health insurance import-export controls, work and resident visas, and trademark policies. Consequently, non-Chinese biotech pharmaceutical MNEs conducting foreign investment in China must understand China's rules and regulations in order to reduce investment-risk levels. Besides, the biotech pharmaceutical industry is a knowledge-intensive industry so that the availability of high-quality research personnel proficient in R \& D activities has became an important factor.

Drug innovation is a necessity for multinational biotech pharmaceutical enterprises' successful international competition. Biotech pharmaceutical enterprises seeking to undertake research and product-development activities should adopt strategies that result in the realization of optimum innovation levels and optimum returns on investment in pursuit of these goals. People with R \& D capability are central to non-Chinese multinational biotech pharmaceutical enterprises seeking to enter China in ways that enable the companies to market innovative products, to improve operational performance, and to gain competitive advantage over rivals. Hence, the current study's weighted calculations strongly suggest that the three most important criteria affecting competitivestrategy selection of FDI to China are capability in dealing with governmental rules and regulations $(\mathrm{C} 1)$, collaboration with local partners (C2), and possession of high-quality research personnel with $\mathrm{R} \& \mathrm{D}$ capability (C9).

\section{Conclusions}

In this study, we have sought to identify the most appropriate competitive strategy for multinational biotech pharmaceutical enterprises that which plan to invest, or have already invested in China. By harnessing an ANP technique that combines both qualitative and quantitative information, we proposed a hierarchical model for competitive strategy selection. The model consists of 1 goal, 3 assessment dimensions, 12 criteria, and 3 alternatives. With the help of interactions between criteria under relationship, tactic and specificity dimensions, the data reflects the reality in a better way. Furthermore, the current study accounts for vagueness, subjectivity, and imprecision by using fuzzy logic. This study's use of fuzzy ANP has revealed that the most suitable competitive 
strategy for MNEs is innovative focus strategy, followed by differentiation strategy and market focus strategy (in the order of descending importance). The results of this study has revealed, moreover, that the three most important criteria affecting the competitive strategy selection of FDI to China are collaboration with local partners, governmental rules and regulations and high-quality research personnel with $\mathrm{R} \& \mathrm{D}$ capability.

Future studies can incorporate more important criteria and competitive strategies to expand and refine the model. In addition, future studies can use this model to research strategy selection as it applies to product categories' fitness for foreign investment.

\section{References}

Allen, R. S.; Helms, M.; Takeda, M.; White, C. S.; White, C. 1999. A comparison of competitive strategies in Japan and the United, SAM Advanced Management Journal 71(1): 24-34.

Barczak, G. 1995. New product strategy, structure, process, and performance in the telecommunications industry, Journal of Product Innovation Management 12(3): 224-234.

doi:10.1111/1540-5885.1230224

Barney, J. B. 1991. Firm resource and sustained competing on resources, Harvard Business Review 73(4): 118-128.

Barney, J. B. 1997. Gaining and Sustaining Competitive Advantage. Massachusetts, MA: Addison-Wesley Publishing Company.

Bernard, J. 2010. What is Strategy [online], [cited 25 January 2011]. Available from Internet: $<$ http://www.ecofine.com/strategy/strategy.htm>.

Bogner, W. C.; Thomas, H.; McGee, J. 1996. A longitudinal study of the competitive positions and entry paths of European firms in the US pharmaceutical industry, Strategic Management Journal 17(2): 85-109. doi:10.1002/(SICI)1097-0266(199602)17:2<85::AID-SMJ785>3.0.CO;2-D

Brandenburger, A. H.; Stuart, H. W. 1996. Value-based business strategy, Journal of Economics and Management Strategy 5: 5-24. doi:10.1111/j.1430-9134.1996.00005.x

Brouthers, K. D. 2002. Institutional, cultural and transaction cost influences on entry mode choice and performance, Journal of International Business Studies 33(2): 203-221.

doi:10.1057/palgrave.jibs.8491013

Business Wire. 2009. China's Biopharmaceutical Industry Report [online], [cited 20 November 2010]. Available from Internet: <http://www.businesswire.com/portal/site/home>.

Chang, D. Y. 1992. Extent Analysis and Synthetic Decision Optimization Techniques and Applications. World Scientific, Singapore.

Chang, D. Y. 1996. Applications of the extent analysis method on fuzzy AHP, European Journal of Operational Research 95: 649-655. doi:10.1016/0377-2217(95)00300-2

Chen, L. M.; Lou, S. H. 2005. The Strategic Alliances for Bio-tech and Pharmaceutical Company. Taipei: Development Center of Biotechnology.

China Research and Intelligence. 2008. Market Report on China's Biopharmaceutical Industry, 2008-2010 [online], [cited 20 November 2010]. Availabe from Internet: <http://prlog. org/10136857>.

Collis, D. J.; Montgomery, C. A. 1995. Competing on resources: strategy in the 1990s, Harvard Business Review 73: 118-128.

Deeds, D. L.; Hill, C. W. L. 1996. Strategic alliances and the rate of new product development: an empirical study of entrepreneurial biotechnology firms, Journal of Business Venturing 11(1): 41-55. doi:10.1016/0883-9026(95)00087-9 
Devrim, D. 2009. An analysis of the determinants of foreign direct investment in Turkey: the role of the institutional context, Journal of Business Economics and Management 10(1): 15-30. doi:10.3846/1611-1699.2009.10.15-30

Dubois, D.; Prade, H. 1978. Operation on fuzzy numbers, International Journal of Systems Sciences 9(6): 613-626. doi:10.1080/00207727808941724

Feltz, T. V. D. 2007. Recruitment perspectives, the future of R \& D leadership, Journal of Medical Marketing 7: 265-267.

Giachetti, R. E.; Young, R. E. 1997. A parametric representation of fuzzy numbers and their arithmetic operators, Fuzzy Sets and Systems 91: 185-202 doi:10.1016/S0165-0114(97)00140-1

Ginevičius, R.; Krivka, A.; Šimkūnaitè, J. 2010. The model of forming competitive strategy of an enterprise under the conditions of oligopolic market, Journal of Business Economics and Management 11(3): 367-395. doi:10.3846/jbem.2010.18

Grant, R. M. 1991. The resource-based view of competitive advantage: implication for strategy formulation, California Management Journal 33: 11-134.

Hafeez, K.; Zhang, Y.; Malak, N. 2002. Core competence for sustainable competitive advantage: a structured methodology for identifying core competence, IEEE Transactions on Engineering Management 49(1): 28-35. doi:10.1109/17.985745

Hoskisson, R. E.; Hitt, M. A.; Ireland, R. D. 2004. Competing for Advantage. Cincinatti, Ohio: South-Western College Publishing Company.

Hyun, H. J. 2006. Quality of institutions and foreign direct investment in countries: causality tests for cross-country panels, Journal of Business Economics and Management 7(3): 103-110.

Kahraman, C.; Ruan, D.; Dogan, I. 2002. Fuzzy group decision-making for facility location selection, Information Sciences 157: 135-153. doi:10.1016/S0020-0255(03)00183-X

Kak, A. 2004. Strategic management, core competencies and flexibility: learning issues for select pharmaceutical organizations, Global Journal of Flexible System Management 5(4): 1-15.

Karimi, A. R.; Mehrdadi, N.; Hashemian, S. J.; Nabi Bidhendi, G. R.; Tavakkoli Moghad, R. 2011. Selection of wastewater treatment process based on the analytical hierarchy process and fuzzy analytical hierarchy process methods, International Journal of Environmental Science and Technology 8(2): 267-280.

Kaufmann, A.; Gupta, M. M. 1988. Fuzzy Mathematical Models in Engineering and Management Science. Amsterdam: North-Holland.

Kirca, A. H.; Jayachandran, S.; Bearden, W. O. 2005. Market orientated: a meta-analytic review and assessment of its antecedent and impact on performance, Journal of Marketing 69(April): 24-41. doi:10.1509/jmkg.69.2.24.60761

Korsakiene, R. 2004. Determining competitive advantage: the analytic hierarchy process, Journal of Business Economics and Management 5(4): 205-215.

Lado, A. A.; Wilson, M. C. 1994. Human resources system and sustained competitive advantage: a competency-based perspective, Academic Management Review 19(4): 699-727.

Lahti, R. M. 1999. Identifying and integrating individual level and organizational level core competencies, Journal of Business and Psychology 14(1): 59-75. doi:10.1023/A:1022906400927

Lee, H. H.; Yang, T. T.; Chen, C. B.; Chen, Y. L. 2011. A fuzzy hierarchy integral analytic expert decision process in evaluating foreign investment entry mode selection for Taiwanese bio-tech firms, Expert Systems with Applications 38(4): 3304-3322. doi:10.1016/j.eswa.2010.08.116

Lei, D.; Hitt, M.; Bettis, R. 1996. Dynamic core competence through meta-learning and strategic context, Journal of Management 22(4): 549-569. doi:10.1177/014920639602200402

Liu, S. S.; Cheng, M. 2000. Toward a framework for entering China's pharmaceutical market, Marketing Intelligence and Planning 18(5): 227-235. doi:10.1108/02634500010343928 
Markides, C. C.; Williamson, P. J. 1994. Related diversification, core competences and corporate performance, Strategic Management Journal 15(Special Issue Summer): 149-165.

Matsuno, K.; Mentzer, J. T. 2000. The effects of strategy type on the market orientation-performance relationship, Journal of Marketing 54: 1-16. doi:10.1509/jmkg.64.4.1.18078

Mehta, S.; Peters, L. S. 2007. Outsourcing a core competency, Research Technology Management 50(3): 28-34.

Meyer, K. E.; Wright, M.; Pruthi, S. 2009. Managing knowledge in foreign entry strategies: a resources-based analysis, Strategic Management Journal 30(5): 557-574. doi:10.1002/smj.756

Mikhailov, L.; Singh, M. G. 1999. Comparison analysis of methods for deriving priorities in the AHP, in Proceeding IEEE Conference Systems, Man, Cybernetics. Tokyo, Japan, 1037-1042.

Miles, R. E.; Snow, C. C. 1978. Organizational Strategy, Structure, and Process. New York, NY: McGraw-Hill.

O'Tegan, N.; Ghobadian, A. 2004. The importance of capabilities for strategic direction and performance, Management Decision 42(1/2): 292-311.

Olson, E. M.; Slater, S. F.; Hult, G. T. M. 2005. The Performance Implications of Fit. Among business strategy, marketing organization structure and strategic behavior, Journal of Marketing 69(July): 49-65. doi:10.1509/jmkg.69.3.49.66362

Petts, N. 1997. Building growth on core competence: a practical approach, Long Range Planning 30(4): 551-561. doi:10.1016/S0024-6301(97)00034-4

Porter, M. E. 1980. Competitive Strategy. New York, NY: Free Press.

Powell, W. W.; Brantley, P. 1992. Competitive cooperation in biotechnology: learning through networks, in Nohria, N.; Eccles, R. (Eds.). Network and Organizations: Structure, Form and Action. Boston, MA: Harvard Business School Press, 365-394.

Prahalad, C. K.; Hamel, G. 1990. The core competence of the corporation, Harvard Business Review 68(3): 79-91.

Richards, M.; DeCarolis, D. M. 2003. Joint venture research and development activity: an analysis of the international biotechnology industry, Journal of International Management 9: 33-49. doi:10.1016/S1075-4253(03)00002-4

Saaty, T. L. 1980. The Analytic Hierarchy Process. New York, NY: McGraw-Hill.

Saaty, T. L. 1996. Decision Making with Dependence and Feedback: the Analytic Network Process. Pittsburgh: RWS Publications.

Saaty, T. L. 2005. Theory and Applications of the Analytic Network Process: Decision Making with Benefits, Opportunities, Costs, and Risks. Pittsburgh, PA: RWS Publications.

Saaty, T. L. 2006. Rank from comparisons and from ratings in the analytic hierarchy/network processes, European Journal of Operational Research 168: 557-570. doi:10.1016/j.ejor.2004.04.032

Sen, Z. 2001. Bulamk Mantk ve Modelleme Ilkeleri. Istanbul, Bilge Kültür Sanat Yaymlan.

Sen, Z. 2003. Modern Mantk. Istanbul: Bilge Kültür Sana.

Shan, W.; Song, J. 1997. Foreign direct investment and the sourcing of technological advantage: evidence from the biotechnology industry, Journal of International Business Studies 28(2): 267-284. doi:10.1057/palgrave.jibs.8490101

Spanos, Y. E.; Lioukas, S. 2001. An examination into the causal logic of performance effects of knowledge management with information technology: roles of dynamic capability, competitive strategy, and strategic fit rent generation: contrasting porter's competitive strategy framework and the resource-based perspective, Strategic Management Journal 22: 907-934. doi:10.1002/smj.174 Stevenson, W. 1996. Production Operations Management. 5th ed. Chicago: Irwin Publishing Company. 
Strandskov, J. 2006. Sourcces of competitive advantages and business performance, Journal of Business Economics and Management 7(3): 119-129.

Swamidass, P. M.; Newell, W. T. 1987. Manufacturing strategy, environmental uncertainty and performance: a path analytic model, Management Science 33(4): 509-524.

doi:10.1287/mnsc.33.4.509

Toni, A. D.; Tonchia, S. 2003. Strategic planning and firm's competencies: traditional approaches and new perspectives, International Journal of Operations and Production Management 23(9): 947-976. doi:10.1108/01443570310491729

Van Laarhoven, P. J. M.; Pedrycz, W. 1983. A fuzzy extension of Saaty's priority theory, Fuzzy Sets and Systems 11(3): 229-241.

Vorhies, D. W.; Morgan, N. A. 2003. A configuration theory assessment of marketing organization fit with business strategy and its relationship with marketing performance, Journal of Marketing 63(1): 100-115. doi:10.1509/jmkg.67.1.100.18588

Wagenknecht, M.; Hampel, R.; Schneider, V. 2001. Computational aspects off fuzzy arithmetics based on Archimedeant-norms, Fuzzy Sets and Systems 123: 49-62.

doi:10.1016/S0165-0114(00)00096-8

Weng, Y.; Yan, C. H.; Tu, F. C. 2010. Outward foreign direct investment and product quality of domestic productions: an empirical investigation, Journal of Business Economics and Management 11(3): 396-414. doi:10.3846/jbem.2010.19

Wernerfelt, B. 1984. A resource-based view of the firm, Strategic Management Journal 5: 171180. doi:10.1002/smj.4250050207

Wolff, G. 2001. The Biotech Investor's Bible. New York, NY: John Wiley and Sons.

Zadeh, L. A. 1965. Fuzzy sets, Information and Control 8: 338-353.

doi:10.1016/S0019-9958(65)90241-X 


\section{APPENDIX}

The definition of assessment criteria and alternatives

\begin{tabular}{ll}
\hline \multicolumn{1}{c}{ Criteria } & \multicolumn{1}{c}{ Definition } \\
\hline $\begin{array}{l}\text { Capability in dealing } \\
\text { with governmental }\end{array}$ & $\begin{array}{l}\text { The biotech pharmaceutical firm can deal with the host country's state- } \\
\text { mandated laws, standards, and guidelines governing such matters as } \\
\text { rules and regulations } \\
\text { (C1) }\end{array}$ \\
$\begin{array}{l}\text { investment-regulation regimes, patent acquisition, drug-pricing systems, } \\
\text { public health insurance, import-export controls, work and resident visas, } \\
\text { and trademark policies. }\end{array}$
\end{tabular}

Collaboration

The biotech pharmaceutical firm can work with local partners in ways that with local partners (C2)

Capability in building relationships with

$\mathrm{R} \& \mathrm{D}$ centers $(\mathrm{C} 3)$ gain the firm quick access to local markets.

Capability in building relationships with universities (C4)

The biotech pharmaceutical firm can develop links with research institutions in the host country to accelerate products' introduction time and to reduce the risk of incurring unnecessary research-and-development expenses.

Capability in building The biotech pharmaceutical firm can develop customer relationships to customer relationships clarify customer needs, to develop needed medicines, and to offer good (C5) sales service.

Support of funding The biotech pharmaceutical firm can obtain sufficient long-term financing (C6) from diverse channels, including initial public offerings, venture capital, or cash flow from product sales.

Building wide channel The biotech pharmaceutical firm can develop diverse sites for channel distributions (C7) distribution, including such sites as hospitals, clinics, pharmacies, and e-commerce establishments.

Marketing capability The biotech pharmaceutical firm can conduct promotional activities through (C8) advertising, public relations, and personal sales to market new products, to acquire high-potential pharmaceutical-product customers, and to help the firm shift its orientation outward to customers and their unmet medical needs.

High-quality research The biotech pharmaceutical firm possesses skilled and talented workers who personnel with R \& D can effectively study and create novel innovative products.

capability (C9)

Excellent information The biotech pharmaceutical firm possesses data-processing mechanisms systems (C10) that strengthen the firm's platform for developing a global, effective supply chain and for establishing industry networks.

Strategic management The biotech pharmaceutical firm can effectively handle international matters of globalization (C11) in pursuit of short- and long-term firm goals, and can specifically familiarize itself with relevant aspects of the host country (e.g., business behaviors there).

Strong brand (C12) The biotech pharmaceutical firm possesses an invaluable trademark reputation that makes specific promises of value embedded in customers' awareness.

Innovative-focus $\quad$ Entering the market with a new patented drug.

strategy (A1)

Differentiation strategy Entering the market by providing a unique, superior, and attractive product (A2) in terms of quality, efficiency, features, design innovations, after-sale customer support, or style.

Market-focus strategy Focusing on specific diseases or ailments to which people in China are (A3) vulnerable (e.g., hepatitis B, diabetes mellitus, asthma, and nasopharyngeal cancer). 
FUZZY METODO TAIKYMAS NUSTATANT KONKURENCINGUMĄ

SKATINANČIAS STRATEGIJAS, NAUDOJAMAS KINIJOJE:

TARPTAUTINIŲ FARMACIJOS KOMPANIJŲ PAVYZDŽIU

\section{Y.-H. Lee}

Santrauka

Straipsnyje analizuojama galimybė nustatyti ir parinkti strategiją, kuri yra tinkamiausia tarptautinèms biotechnologinèms farmacijos kompanijoms ir padètu joms konkurencinèje aplinkoje. Autoriai taikè analitinį tinklo formavimo metodą (ANP), derindami kokybinę ir kiekybinę informaciją bei duomenis, kurie buvo skirti hierarchiniam modeliui formuoti. Analizuojant ivvairius verslo strategijos veiksnius ir pritaikius Fuzzy logic metodą, buvo pašalinta neapibréžtumo sąlyga, kuri dažnai siejama su subjektyvumu ir netikslumais, atsirandančiais dẻl žmogiškojo veiksnio / sprendimo. Gauti rezultatai rodo, kad tarptautinėms biotechnologinėms farmacijos kompanijoms viena tinkamiausių strategijų, didinančių konkurencingumą, yra inovatyvi fokusinè strategija.

Reikšminiai žodžiai: konkurencija, strategija, Fuzzy metodas, tarptautinès kompanijos, farmacijos i̇monès.

Yun-Huei LEE. An Assistant Professor of Business Administration at Tamkang University in Taiwan. She received her Ph.D. in Business Management from the National Dong Hwa University in 2008. Her research interests include empirical exploration of strategic issues, more specifically focusing on international market entry strategy and new product development of technology management. 